\title{
KUALITAS PELAYANAN PUBLIK DALAM PEMBUATAN IZIN TRAYEK OLEH DLLAJ KABUPATEN BOGOR
}

\section{EFFECTIVENESS OF PUBLIC SERVICE IN SERVICE BY DLLAJ ROUTE PERMITS BOGOR DISTRICT}

\author{
Tedi Helmi ${ }^{1}$,R. Akhmad Munjin ${ }^{2}$, Irma Purnamasari ${ }^{3}$ \\ ${ }^{1}$ Jurusan Ilmu Administrasi Negara Fakultas Imu Sosial dan Ilmu Politik Universitas Djuanda, Jl.Tol \\ Ciawi No 1, Kotak Pos 35 Bogor 16770 \\ 2 Jurusan Ilmu Administrasi Negara Fakultas Imu Sosial dan Ilmu Politik Universitas Djuanda, Jl.Tol \\ Ciawi No 1, Kotak Pos 35 Bogor 16770 \\ ${ }^{3}$ Jurusan Ilmu Administrasi Negara Fakultas Imu Sosial dan Ilmu Politik Universitas Djuanda, Jl.Tol \\ Ciawi No 1, Kotak Pos 35 Bogor 16770
}

(Diterima oleh Dewan Redaksi: 01-02-2016)

(Dipublikasikan oleh Dewan Redaksi: 01-04-2016)

\begin{abstract}
The purpose of this study is: To determine the quality of service route permits by DLLAJ Bogor. The method used in this study is a survey method, whereas other types of research using descriptive method of research was conducted to determine the value of an independent variable, either one or more variables (independent) without making comparisons, or connect with other variables. The population in this study is the number of recipients of route permits issued by DLLAJ Bogor district of 72 tracks with as many as 6699 route. The sampling technique that uses Simple Random Sampling method. Analysis of the data in this study is a quantitative analysis using Likert Scale and Weight Means Score analysis formula. The results showed that the public perception of the effectiveness of service of route permits by DLLAJ Bogor Regency has been performing well, with a total score of 3.45. This means that the service delivery route permits by DLLAJ Bogor Regency indicates that the level of service has been good, but still needs to be improved in terms of both efficiency and its participatory
\end{abstract}

Keyword: Quality, Service Delivery, Performance, Route Permit,

\begin{abstract}
ABSTRAK
Tujuan penelitian ini adalah : Untuk mengetahui kualitas pelayanan izin trayek oleh DLLAJ Kabupaten Bogor. Metode yang digunakan dalam penelitian ini adalah metode survey, sedangkan jenis penelitian menggunakan metode deskriptifyaitu adalah penelitian yang dilakukan untuk mengetahui nilai variabel mandiri, baik satu variabel atau lebih (independen) tanpa membuat perbandingan, atau menghubungkan dengan variabel yang lain. Populasi dalam penelitian ini adalah jumlah penerima izin trayek yang dikeluarkan oleh DLLAJ kabupaten Bogor dari 72 lintasan dengan sebanyak 6699 trayek. Adapun teknik pengambilan sampel yaitu menggunakan metode Simple Random Sampling. Analisis data dalam penelitian ini adalah analisis kuantitatif dengan menggunakan Skala Likert dan rumus analisis Weight Means Score. Hasil penelitian menunjukan bahwaPersepsi masyarakat terhadap efektifitas pelayanan izin trayek oleh DLLAJ Kabupaten Bogor sudah terlaksana dengan baik, dengan jumlah skor 3,45. Hal ini berarti bahwa penyelenggaraan
\end{abstract}


pelayanan izin trayek oleh DLLAJ Kabupaten Bogor menandakan bahwa tingkat pelayanannya sudah baik, namun masih perlu ditingkatkan baik dari segi efisiensi maupun partisipatifnya

Keyword : Kualitas, Pelayanan Publik, Kinerja, Izin Trayek.

Tedi Helmi, 2016, Kualitas Pelayanan Publik Dalam Pembuatan Izin Trayek Oleh DLLAJ Kabupaten Bogor. Jurnal Governansi. 


\section{PENDAHULUAN}

Pelayanan merupakan tugas utama bagi aparatur negara sebagai abdi negara dan abdi masyarakat. Tugas ini secara jelas telah digariskan dalam pembukaan Undang - Undang Dasar 1945 alinea Ke empat, yang meliputi empat aspek pelayanan pokok aparatur terhadap masyarakat yang berbunyi : "Melindungi segenap bangsa dan seluruh tumpah darah Indonesia memajukan kesejahteraan umum dan mencerdaskan kehidupan bangsa". Pelayanan publik merupakan salah satu tugas penting yang tidak dapat diabaikan oleh pemerintah daerah sebab jika komponen Pelayanan terjadi stagnasi maka hampir dipastikan semua sektor akan berdampak kemacetan oleh sebab itu perlu ada perencanaan yang baik dan bahkan perlu diformulasikan standar pelayanan pada masyarakat sesuai dengan kewenangan yang diberikan oleh pemerintah pusat pada pemerintah daerah. Sebagai konsekuensi dari pelaksanaan Otonomi Daerah terlebih setelah ditetapkannya Undang - Undang Nomor 23 Tahun 2014 tentang Pemerintahan Daerah, dimana Pemerintahan Daerah diberi kewenangan yang demikian luas oleh pemerintah pusat yang bersifat konkuren, urusan pemerintahan konkuren yang diserahkan ke daerah menjadi dasar pelaksanaan Otonomi Daerah (pasal 9(4) UU nomor 23 tahun2014).

Berdasarkan Undang-undang nomor 23 tahun 2014, Urusan pemerintahan konkuren sebagaimana di maksud dalam Pasal 9 ayat (3) yang menjadi kewenangan Daerah terdiri atas Urusan Pemerintahan Wajib dan Urusan Pemerintahan Pilihan, Urusan Pemerintahan Wajib terdiri atas Urusan Pemerintahan yang berkaitan dengan Pelayanan Dasar dan Urusan Pemerintahan yang tidak berkaitan dengan Pelayanan Dasar.

Urusan Pemerintahan Wajib yang berkaitan dengan Pelayanan Dasar meliputi:

a. pendidikan; b. kesehatan;

c. pekerjaan umum dan penataan ruang;

d. perumahan rakyat dan kawasan permukiman;

e. ketenteraman, ketertiban umum, dan pelindunganmasyarakat; dan

f. sosial.

Urusan Pemerintahan Wajib yang tidak berkaitan dengan Pelayanan Dasar meliputi:

a. tenaga kerja;

b. pemberdayaan perempuan dan pelindungan anak;

c. pangan;

d. pertanahan;

e. lingkungan hidup;

f. administrasi kependudukan dan pencatatan sipil;

g. pemberdayaan masyarakat dan Desa;

h. pengendalian penduduk dan keluarga berencana;

i. perhubungan;

j. komunikasi dan informatika;

k. koperasi, usaha kecil, dan menengah;

l. penanaman modal;

m. kepemudaan dan olah raga;

n. statistik;

o. persandian;

p. kebudayaan;

q. perpustakaan; dan

r. kearsipan.

Urusan Pemerintahan Pilihan meliputi:

a. kelautan dan perikanan;

b. pariwisata;

c. pertanian;

d. kehutanan;

e. energi dan sumber daya mineral;

f. perdagangan;

g. perindustrian; dan

h. transmigrasi.

Berangkat dari tataran formal tersebut, perhubungan sebagai salah satu bidang yang dilaksanakan oleh daerah memiliki peranan penting dalam menunjang dan mendorong pertumbuhan pembangunan di sektor perhubungan yang berakibat pula dalam penyiapan pelayanan umum sarana, prasarana dan fasilitas perhubungan. Pentingnya transportasi 
tercermin pada semakin meningkatnya kebutuhan akan jasa angkutan bagi mobilitas orang serta barang dari dan ke seluruh pelosok tanah air, dengan adanya peningkatan kebutuhan akan jasa mobilitas orang dan barang, maka Dinas LLAJ mempunyai peranan penting dalam pengelolaan dan pengolahan Proses Ijin Trayek Angkutan Penumpang Umum.

Berdasarkan hasil wawancara peneliti dengan masyarakat yang sudah mengurus izin trayek, dan berdasarkan pengamatan peneliti dalam pelayanan izin trayek masih terdapat masalah. Hal ini terlihat dari indikator proses perizinan yang memerlukan waktu 14 hari, waktu ini terlalu lama jika dibandingkan dengan proses perpanjangan STNK atau KIR, serta biaya perpanjangan izin trayek yang kurang transparan walau masih terjangkau dimana tidak adanya papan tarif resmi yang dipasang.

Berdasarkan latar belakang diatas penulis merumuskan masalahnya yaitu bagaimanakah kualitas pelayanan izin trayek oleh DLLAJ Kabupaten Bogor?Guna mengetahui kualitas pelayanan izin trayek oleh DLLAJ Kabupaten Bogor telah dilakukan penelitian lapangan dengan metode survey dan angket kepada para penerima izin trayek dari 72 lintasan.

Berdasarkan hal tersebut tujuan dari penelitian ini adalah untuk mengetahui kualitas pelayanan izin trayek oleh DLLAJ Kabupaten Bogor.

\section{MATERI DAN METODE}

Metode yang digunakan dalam penelitian ini adalah metode deskriptif, yaitu adalah penelitian yang dilakukan untuk mengetahui nilai variabel mandiri, baik satu variabel atau lebih (independen) tanpa membuat perbandingan, atau menghubungkan dengan variabel yang lain ( Sugiono, 2013: 35 ). Penelitian dilaksanakan di DLLAJ Kabupaten Bogor, Jl. Raya Jakarta Km 50 Cimandala - Bogor 16710. Penelitian berlangsung dari Desember 2015 sampai dengan Februari 2016.

\section{Populasi dan Sampel}

Populasi dari penelitian ini adalah jumlah penerima izin trayek yang dikeluarkan oleh DLLAJ kabupaten Bogor dari 72 lintasan dengan sebanyak 6699 trayek.

Sampel yang digunakan dalam penelitian ini diambil dari 72 izin trayek yang dikeluarkan oleh DLLAJ yang berasal dari 72 pemilik angkutan umum, penulis menggunakan metode Simple Random Sampling, teknik ini digunakan bila populasi dianggap homogen (Sugiono, 2013 : 81) dan presisi/tingkat kesalahan yang ditentukan yaitu 0,1 . Ukuran sampel tersebut dengan menggunakan rumus Slovin (Riduwan, 2005: 65) sebagai berikut:

$$
\begin{aligned}
& \mathrm{N} \\
& \mathrm{n}=- \\
& \mathrm{N}\left(\mathrm{d}^{2}\right)+1 \\
& \text { Dimana : } \\
& \mathrm{n} \quad \text { : Ukuran sampel } \\
& \mathrm{N} \quad \text { : Ukuran populasi } \\
& \mathrm{d} \quad \text { : Presisi }(0,1)
\end{aligned}
$$

Berdasarkan rumus di atas maka dihitung besarnya sampel sebagai berikut :

72

$$
\begin{aligned}
\mathrm{n}= & \\
\mathrm{n}= & 42(0,1)^{2}+1 \\
&
\end{aligned}
$$

\section{Teknik Pengumpulan Data}

1. Studi Kepustakaan

Yaitu teknik pengumpulan data dari sumber-sumber tertulis yang sifatnya teoritis sehubungan dengan bidang penelitian. Penelaahan dimaksudkan untuk mendapatkan informasi yang lengkap serta menentukan tindakan yang akan dilaksanakan kemudian dalam kerangka kegiatan ilmiah. Menurut Masri Singarimbun (1987) manfaat kepustakaan adalah : 
a. Menggali teori dasar dan konsep yang telah dikemukakanoleh ahli terdahulu

b. Mengikuti perkembangan penelitian dalam bidang yang akan diteliti

c. Memperoleh orientasi yang lebih luas mengenai topik yang dipilih

d. Memanfaatkan data sekunder

e. Menghindari duplikasi penelitian

2. Studi Lapangan

Yaitu teknik pengumpulan data

melalui pengamatan secara langsung ke tempat penelitian dengan cara sebagai berikut :

- Observasi; mengamati pelanggaran yang terjadi di jalan raya dimana masih ada pengemudi yang mengemudikan kendaraannya yang telah habis izin trayeknya

- Wawancara; melakukan Tanya jawab secara langsung/tidak langsung berdasarkan pedoman wawancara dengan tujuan untuk memperoleh informasi mengenai pelayanan izin trayek

- Angket; merupakan sejumlah pertanyaan tertulis dan terstruktur bagi responden untuk memperoleh informasi dari responden. Sifat angketnya adalah "tertutup" maksudnya adalah alternatif jawaban atas pertanyaan yang diajukan sudah disediakan oleh peneliti sehingga responden tinggal memilih alternatif jawaban yang sesuai dengan pendapatnya.

\section{TeknikAnalisa Data}

Teknik analisis data yang digunakan dalam pembahasan uji hipotesis dalam penelitian ini ada dua macam teknik, yaitu :

1. Untuk kajian mendalam digunakan skala Likert, berupa penghitungan tabulasi angket yang bergradasi dan kemudian diberikan kerangka penafsiran. Skala Likert menurut Djaali (2008:28) ialah skala yang dapat dipergunakan untuk mengukur sikap, pendapat, dan persepsi seseorang atau sekelompok orang tentang suatu gejala atau fenomena pendidikan. Skala Likert adalah suatu skala psikometrik yang umum digunakan dalam kuesioner, dan merupakan kala yang paling banyak digunakan dalam riset berupa survei. Nama skala ini diambil dari nama Rensis Likert, pendidik dan ahli psikolog Amerika Serikat. Dengan Skala Likert, variabel yang akan diukur dijabarkan menjadi indicator variabel. Kemudian indicator tersebut dijadikan sebagai titik tolak untuk menyusun item-item instrumen yang dapat berupa pertanyaan atau pernyataan. Dalam hal ini skala likert mempunyai gradasi dari sangat positif sampai sangat negatif, peneliti menggunakan gradasi lima, yaitu :Sangat Setuju, Setuju, Kurang Setuju, Tidak Setuju Sangat Tidak Setuju. Untuk jawaban tersebut diberi skor sebagai berikut :

- Respondengannilaiskor berartiSangat Setuju

- Respon dengan nilai skor 4 berarti Setuju

- Respon dengan nila iskor 3 berarti Kurang Setuju

- Respon dengan nila iskor 2 berarti Tidak Setuju

- Respondengan nilai skor 1 berarti Sangat Tidak Setuju

Dengan demikian diperoleh variasi skor yang bergerak dari angka 1 hingga 5 . Untuk itu interval antara satu kriteria dengan kriteria lainnya diperoleh angka 0,8 dengan cara pengurangan nilai skor tertinggi (5) oleh nilai terendah (1), kemudian dibagi oleh banyaknya kriteria (ada 5). Perhitungannya adalah :

$$
\frac{5-1}{5}=0,8
$$

Maka diperoleh kriteria penafsiran responden sebagai berikut :

1,00 - 1,80 berarti Tidak Baik 
1,81 - 2,61 berarti Kurang Baik

2,61 - 3,41 berarti Cukup Baik

3,41 - 4,21 berarti Baik

4,20 - 5,00 berarti Sangat Baik

Sumber : Sugiyono (2013 : 93)

2. Untuk memperoleh penafsiran atau interpretasi digunakan rumus Bakrie Siregar (1981: 20) analisis Weight Means Score, dengan rumus sebagai berikut:

$\mathbf{M}=\boldsymbol{\Sigma} \mathbf{f} \mathbf{x}$

$$
\text { n }
$$

\section{Keterangan :}

M = Perolehan angka penafsiran

f $\quad$ frekuensi

$\mathbf{x}=$ pembobotan skala nilai (skor)

$\boldsymbol{\Sigma} \quad=$ Penjumlahan

n = Jumlah responden

Maka diperoleh kriteria penafsiran responden sebagai berikut :

\section{1,00 - 1,80 berarti Tidak Baik}

1,81 - 2,61 berarti Kurang Baik

2,61 - 3,41 berarti Cukup baik

3,41 - 4,21 berarti Baik

4,20 - 5,00 berartiSangatBaik

\section{HASIL DAN PEMBAHASAN}

Proses analisis data dimulai setelah pengedaran dan pengumpulan seluruh angket yang berjumlah 42, kemudian diperiksa keabsahannya. Dari hasil penelitian yang dilakukan penulis tentang kualitas pelayanan izin trayek oleh DLLAJ Kabupaten Bogor, sesuai dengan yang telah ditentukan dalam operasionalisasi variabel, kualitas pelayanan izin trayek oleh DLLAJ Kabupaten Bogor ini terdiri dari 6 dimensi dan 10 indikator yaitu:

1. Dimensi Transparansi dengan indikator keterbukaan proses penyelenggaraan pelayanan publik, peraturan dan prosedur pelayanan yang dapat dipahami, kemudahan untuk memperoleh informasi mengenai berbagai aspek penyelenggaraan pelayanan publik

2. Dimensi Akuntabilitas dengan indikator kinerja pelayanan publik, biaya pelayanan publik

3. Dimensi Kondisional dengan indikator pelayanan yang efisien dan efektif

4. Dimensi Partisipatif dengan indikator peran masyarakat

5. Dimensi Kesamaan Hak dengan indikator pelayanan yang tidak membeda-bedakan status sosial dan lainnya

6. Dimensi Keseimbangan Hak dan Kewajiban dengan indikator pelayanan yang mempertimbangkan aspek keadilan

Tanggapan Responden Tentang keterbukaan proses penyelenggaraan pelayanan publik

\begin{tabular}{|c|c|c|c|c|c|}
\hline No & Alternatif Jawaban & f & $\mathbf{x}$ & $\mathbf{f}\{\mathbf{x}\}$ & $M=\sum f(x) / n$ \\
\hline 1 & Sangat Setuju & 0 & 5 & 0 & $168 / 42$ \\
\hline 2 & Setuju & 42 & 4 & 168 & \\
\hline 3 & Kurang Setuju & 0 & 3 & 0 & \\
\hline 4 & Tidak Setuju & 0 & 2 & 0 & \\
\hline \multirow[t]{2}{*}{5} & Sangat Tidak Setuju & 0 & 1 & 0 & \\
\hline & JUMLAH & 42 & & 168 & 4 \\
\hline
\end{tabular}


Berdasarkan hasil perhitungan di atas 4 yang termasuk dalam kriteria Baik. Hal ini menunjukan bahwa dari 42 responden yang menunjukan bahwa rata-rata responden menjawab Setuju sebanyak 42 merasa puas dengan pelayanan yang responden,Sehingga hasil angka penafsiran diberikan oleh DLLAJ Kabupaten Bogor dalam yang dihasilkan dari tabel 4.4 adalah sebesar dalam pengurusan izin trayek.

Tanggapan Responden Tentang peraturan dan prosedur pelayanan yang dapat dipahami

\begin{tabular}{clcccc} 
& & $\mathbf{n}=\mathbf{4 2}$ & \\
\hline No & Alternatif Memadai & $\mathbf{f}$ & $\mathbf{x}$ & $\mathbf{f}\{\mathbf{x}\}$ & $\mathbf{M}=\boldsymbol{\Sigma} \mathbf{f}(\mathbf{x}) / \mathbf{n}$ \\
1 & Sangat Setuju & 0 & 5 & 0 & $159 / 42$ \\
2 & Setuju & 33 & 4 & 132 & \\
3 & Kurang Setuju & 9 & 3 & 27 & \\
4 & Tidak Setuju & 0 & 2 & 0 & \\
5 & Sangat Tidak Setuju & 0 & 1 & 0 & $\mathbf{3 , 7 8}$ \\
& $\quad$ JUMLAH & $\mathbf{4 2}$ & & $\mathbf{1 5 9}$ & \\
& & & & &
\end{tabular}

Berdasarkan hasil perhitungan di atas menunjukan bahwa dari 42 responden yang menjawab Setuju sebanyak 33 responden, dan yang menjawab Kurang Setuju 9 responden. Sehingga hasil angka penafsiran yang dihasilkan dari tabel 4.5 adalah sebesar 3,78 yang termasuk dalam kriteria Baik. Hal ini menunjukan bahwa peraturan dan prosedur dalam mengurus izin trayek dapat dipahami oleh masyarakat yang mengurus izin trayek.

Tanggapan Responden Tentang kemudahan untuk memperoleh informasi mengenai berbagai aspek penyelenggaraan pelayanan publik

\begin{tabular}{clcccc}
\multicolumn{1}{c}{$\mathbf{n = 4 2}$} & & & \\
\hline No & $\quad$ Alternatif Jawaban & $\mathbf{f}$ & $\mathbf{x}$ & $\mathbf{f}\{\mathbf{x}\}$ & $\mathbf{M}=\sum \mathbf{f}(\mathbf{x}) / \mathbf{n}$ \\
1 & Sangat Setuju & 0 & 5 & 0 & $168 / 42$ \\
2 & Setuju & 42 & 4 & 168 & \\
3 & Kurang Setuju & 0 & 3 & 0 & \\
4 & Tidak Setuju & 0 & 2 & 0 & \\
5 & Sangat Tidak Setuju & 0 & 1 & 0 & $\mathbf{4}$ \\
& $\quad$ JUMLAH & $\mathbf{4 2}$ & & $\mathbf{1 6 8}$ & \\
\hline
\end{tabular}

Berdasarkan hasil perhitungan di atas menunjukan bahwa dari 42 responden yang menjawab Setuju sebanyak 42 responden. Sehingga hasil angka penafsiran yang dihasilkan dari tabel 4.6 adalah sebesar 4 yang termasuk dalam kriteria Baik. Hal ini menunjukan bahwa masyarakat yang akan mengurus izin trayek mudah memperoleh informasi mengenai berbagai aspek dalam pengurusan izin trayek, dimana setiap petugas yang ditanya akan selalu memberikan informasi yang dibutuhkan. 


\section{Tanggapan Responden Tentang kinerja pelayanan publik}

\begin{tabular}{clcccc}
\multicolumn{5}{c}{$\mathbf{n = 4 2}$} \\
No & Alternatif Jawaban & $\mathbf{f}$ & $\mathbf{x}$ & $\mathbf{f}\{\mathbf{x}\}$ & $\mathbf{M}=\Sigma \mathbf{f}(\mathbf{x}) / \mathbf{n}$ \\
1 & Sangat Setuju & 0 & 5 & 0 & $157 / 42$ \\
2 & Setuju & 31 & 4 & 124 & \\
3 & Kurang Setuju & 11 & 3 & 33 & \\
4 & Tidak Setuju & 0 & 2 & 0 & \\
5 & Sangat Tidak Setuju & 0 & 1 & 0 & \\
& $\quad$ JUMLAH & $\mathbf{4 2}$ & & $\mathbf{1 5 7}$ & $\mathbf{3 , 7 3}$ \\
\hline
\end{tabular}

Berdasarkan hasil perhitungan di atas menunjukan bahwa dari 42 responden yang menjawab Setuju sebanyak 31 responden, yang menjawab Kurang Setuju sebanyak 11 responden. Sehingga hasil angka penafsiran yang dihasilkan dari tabel
4.7 adalah sebesar 3,73 yang termasuk dalam kriteria Baik. Hal ini menunjukan bahwa para petugas di loket pelayanan sudah memberikan pelayanan yang optimal.

Tanggapan Responden Tentang biaya pelayanan publik

\begin{tabular}{clcccc}
\multicolumn{5}{c}{$\mathbf{n}=\mathbf{4 2}$} \\
No & $\quad$ Alternatif Jawaban & $\mathbf{f}$ & $\mathbf{x}$ & $\mathbf{f}\{\mathbf{x}\}$ & $\mathbf{M}=\Sigma \mathbf{f}(\mathbf{x}) / \mathbf{n}$ \\
1 & Sangat Setuju & 0 & 5 & 0 & $168 / 42$ \\
2 & Setuju & 42 & 4 & 168 & \\
3 & Kurang Setuju & 0 & 3 & 0 & \\
4 & Tidak Setuju & 0 & 2 & 0 & \\
5 & Sangat Tidak Setuju & 0 & 1 & 0 & $\mathbf{4}$ \\
\hline
\end{tabular}

Berdasarkan hasil perhitungan di atas menunjukan bahwa dari 42 responden yang menjawab Setuju sebanyak 42 responden. Sehingga hasil angka penafsiran yang dihasilkan dari tabel 4.8 adalah sebesar 4 yang termasuk dalam kriteria Baik. Hal ini menunjukan bahwa biaya dalam pengurusan izin trayek masih terjangkau masyarakat. 


\section{Tanggapan Responden Tentang efisiensi dalam pelayanan publik} $\mathrm{n}=\mathbf{4 2}$

\begin{tabular}{clcccc}
\hline No & Alternatif Jawaban & $\mathbf{f}$ & $\mathbf{x}$ & $\mathbf{f}\{\mathbf{x}\}$ & $\mathbf{M}=\boldsymbol{\Sigma} \mathbf{f}(\mathbf{x}) / \mathbf{n}$ \\
1 & Sangat Setuju & 0 & 5 & 0 & $98 / 42$ \\
2 & Setuju & 0 & 4 & 0 & \\
3 & Kurang Setuju & 14 & 3 & 42 & \\
4 & Tidak Setuju & 28 & 2 & 56 & \\
5 & Sangat Tidak Setuju & 0 & 1 & 0 & \\
& JUMLAH & $\mathbf{4 2}$ & & $\mathbf{9 8}$ & $\mathbf{2 , 3 3}$ \\
\hline
\end{tabular}

Berdasarkan hasil perhitungan di atas menunjukan bahwa dari 42 responden yang menjawab Kurang Setuju sebanyak 14 responden, yang menjawab Tidak Setuju sebanyak 28 responden. Sehingga hasil angka penafsiran yang dihasilkan dari tabel 4.9 adalah sebesar 2,33 yang termasuk dalam kriteria kurang Baik. Hal ini menunjukan bahwa pelayanan yang diberikan dalam pengurusan izin trayek tidak efisien dimana waktu yang dibutuhkan dalam mengurus izin trayek terlalu lama yaitu 2 minggu dari berkas lengkap, jika dibandingkan dengan pengurusan STNK yang beres dalam 1 hari.

Tanggapan Responden Tentang Pelayanan yang efektif

\begin{tabular}{|c|c|c|c|c|c|}
\hline No & Alternatif Jawaban & f & $\mathbf{x}$ & $f\{x\}$ & $M=\sum f(x) / n$ \\
\hline 1 & Sangat Setuju & 0 & 5 & 0 & $163 / 42$ \\
\hline 2 & Setuju & 37 & 4 & 148 & \\
\hline 3 & Kurang Setuju & 5 & 3 & 15 & \\
\hline 4 & Tidak Setuju & 0 & 2 & 0 & \\
\hline \multirow[t]{2}{*}{5} & Sangat Tidak Setuju & 0 & 1 & 0 & \\
\hline & JUMLAH & 42 & & 163 & 3,88 \\
\hline
\end{tabular}

Berdasarkan hasil perhitungan di atas menunjukan bahwa dari 42 responden yang menjawab Setuju sebanyak 37 responden, yang menjawab Kurang Setuju sebanyak 5 responden. Sehingga hasil angka penafsiran yang dihasilkan dari tabel
4.10 adalah sebesar 3,88 yang termasuk dalam kriteria Baik. Hal ini menunjukan bahwa pelayanan yang diberikan sudah efektif dimana sumber daya, sarana dan prasarana dalam mengurus izin trayek sudah memadai. 
Tanggapan Responden Tentang peran masyarakat

$\mathrm{n}=42$

\begin{tabular}{clcccc}
\hline No & Alternatif Jawaban & $\mathbf{f}$ & $\mathbf{x}$ & $\mathbf{f}\{\mathbf{x}\}$ & $\mathbf{M}=\boldsymbol{\Sigma} \mathbf{f}(\mathbf{x}) / \mathbf{n}$ \\
1 & Sangat Setuju & 0 & 5 & 0 & $86 / 42$ \\
2 & Setuju & 0 & 4 & 0 & \\
3 & Kurang Setuju & 8 & 3 & 24 & \\
4 & Tidak Setuju & 28 & 2 & 56 & \\
5 & Sangat Tidak Setuju & 6 & 1 & 6 & \\
& JUMLAH & $\mathbf{4 2}$ & & $\mathbf{8 6}$ & $\mathbf{2 , 0 4}$ \\
\hline
\end{tabular}

Berdasarkan hasil perhitungan di atas menunjukan bahwa dari 42 responden yang menjawab Kurang Setuju sebanyak 8 responden, yang menjawab Tidak Setuju sebanyak 28 responden, dan yang Sangat Tidak Setuju sebanyak 6 responden. Sehingga hasil angka penafsiran yang dihasilkan dari tabel 4.11 adalah sebesar 2,04 yang termasuk dalam kriteria Kurang
Baik. Hal ini menunjukan bahwa dalam pelayanan izin trayek kurang memperhatikan aspirasi, kebutuhan, dan harapan masyarakat dimana harapan masyarakat jangan ada penambahan izin trayek yang baru tapi kenyataannya banyak trayek baru yang dikeluarkan sehingga menyebabkan membludaknya angkot yang beroperasi di jalan.

Tanggapan Responden Tentang Pelayanan yang tidak tidak membeda-bedakan status sosial dan lainnya

$n=42$

\begin{tabular}{|c|c|c|c|c|c|}
\hline No & Alternatif Jawaban & $\mathbf{f}$ & $\mathbf{x}$ & $f\{x\}$ & $M=\sum f(x) / n$ \\
\hline 1 & Sangat Setuju & 0 & 5 & 0 & $150 / 42$ \\
\hline 2 & Setuju & 29 & 4 & 116 & \\
\hline 3 & Kurang Setuju & 8 & 3 & 24 & \\
\hline 4 & Tidak Setuju & 5 & 2 & 10 & \\
\hline \multirow[t]{2}{*}{5} & Sangat Tidak Setuju & 0 & 1 & 0 & \\
\hline & JUMLAH & 42 & & 150 & 3,57 \\
\hline
\end{tabular}

Berdasarkan hasil perhitungan di atas menunjukan bahwa dari 42 responden yang menjawab Setuju sebanyak 29 responden, yang menjawab Kurang Setuju sebanyak 8 responden, dan yang Tidak Setuju sebanyak 5 responden. Sehingga hasil angka penafsiran yang dihasilkan dari tabel 4.12 adalah sebesar 3,57 yang termasuk dalam kriteria Baik. Hal ini menunjukan bahwa dalam melayani masyarakat yang mengurus izin trayek semua diberikan pelayanan yang sama tanpa kecuali. 


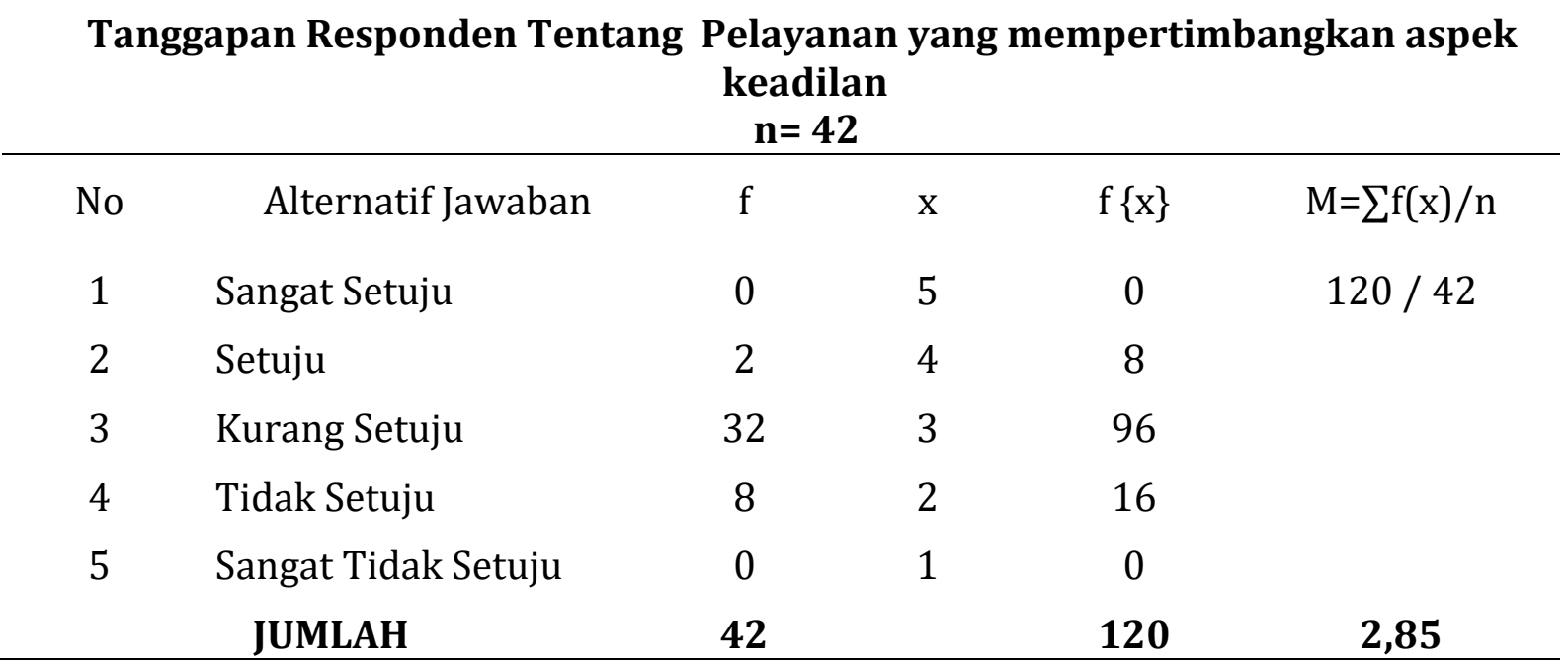

Berdasarkan hasil perhitungan di atas menunjukan bahwa dari 42 responden yang menjawab Setuju sebanyak 2 responden, yang menjawab Kurang Setuju sebanyak 32 responden, dan yang Tidak Setuju sebanyak 8 responden. Sehingga hasil angka penafsiran yang dihasilkan dari tabel 4.13 adalah sebesar 2,85 yang termasuk dalam kriteria Cukup Baik. Hal ini menunjukan bahwa dalam pelayanan izin trayek cukup adil, dimana keseimbangan hak dan kewajiban antara pemberi dan penerima izin trayek sudah terpenuhi walaupun belum sepenuhnya.

Rekapitulasi Jawaban Responden tentang Efektivitas Pelayanan Publik dalam Pelayanan Izin Trayek Oleh DLLAJ KABUPATEN BOGOR Berdasarkan Skala Likert $n=42$

\begin{tabular}{|c|c|c|c|}
\hline No & Dimensi & $\begin{array}{c}\text { Angka } \\
\text { penafsiran }\end{array}$ & Kriteria \\
\hline 1 & $\begin{array}{l}\text { keterbukaan proses penyelenggaraan } \\
\text { pelayanan publik }\end{array}$ & 4 & Baik \\
\hline 2 & $\begin{array}{l}\text { peraturan dan prosedur pelayanan yang } \\
\text { dapat dipahami }\end{array}$ & 3,78 & Baik \\
\hline 3 & $\begin{array}{l}\text { kemudahan untuk memperoleh } \\
\text { informasi mengenai berbagai aspek } \\
\text { penyelenggaraan pelayanan publik }\end{array}$ & 4 & Baik \\
\hline 4 & kinerja pelayanan publik & 3,73 & Baik \\
\hline 5 & biaya pelayanan publik & 4 & Baik \\
\hline 6 & Pelayanan yang efisien dan efektif & 3,10 & Cukup Baik \\
\hline 7 & peran masyarakat & 2,04 & Kurang Baik \\
\hline 8 & $\begin{array}{l}\text { Pelayanan yang tidak tidak membeda- } \\
\text { bedakan status sosial dan lainnya }\end{array}$ & 3,57 & Baik \\
\hline 9 & $\begin{array}{l}\text { Pelayanan yang mempertimbangkan } \\
\text { aspek keadilan }\end{array}$ & 2,85 & Cukup Baik \\
\hline & Rata-rata & 3,45 & Baik \\
\hline
\end{tabular}


Dari rekapitulasi diatas menunjukan hasil angka penafsiran yang dihasilkan sebesar 3.45 yang termasuk dalam kriteria penilaian Baik. Hal ini menunjukan bahwa pelayanan izin trayek oleh DLLAJ Kabupaten sudah terlaksana dengan baik.

\section{KESIMPULAN DAN SARAN Kesimpulan}

Persepsi masyarakat terhadap kualitas pelayanan izin trayek oleh DLLAJ Kabupaten Bogor sudah terlaksana dengan baik, dengan jumlah skor 3,45. Hal ini terbukti dari hasil jawaban para responden berdasarkan hasil penelitian dari indikator diatas. Dari sembilan indikator tersebut yang menunjukkan hasil responden berada pada kategori baik.Hal ini berarti bahwa penyelenggaraan pelayanan izin trayek oleh DLLAJ Kabupaten Bogor menandakan bahwa tingkat pelayanannya sudah baik, namun masih perlu ditingkatkan baik dari segi efisiensi maupun partisipatifnya.

\section{Saran}

Berdasarkan hasil kesimpulan, diusulkan beberapa saran yang dapat menjadi bahan pertimbangan bagi DLLAJ Kabupaten Bogor dalam meningkatkan pelayanan izin trayek, antara lain sebagai berikut :

1. DLLAJ Kabupaten Bogor agar bisa lebih meningkatkan pelayanan khususnya layanan izin. Memperhatikan dalam segi peningkatan kualitas, kemudahan, ketepatan waktu, ekonomis, serta memperhatikan aspirasi, kebutuhan, dan harapan masyarakat dalam memberikan pelayanan.

2. Perlu adanya prosedur/tatacara pelayanan diselenggarakan secara mudah, cepat, tepat, tidak berbelitbelit dan mudah dipahami dan mudah dilaksanakan oleh masyarakat yang meminta pelayanan sehingga ada kejelasan dan kepastian (transparan)

Dilakukan moratoriun izin trayek, kemudian disesuaikan dengan pertumbuhan jalan di Kabupaten Bogor.

\section{DAFTAR PUSTAKA}

Adrian Sutedi. (2010) Hukum Perizinan Dalam Sektor Pelayanan. Publik. Jakarta: Sinar Grafika

Agus Dwiyanto. (2005) Mewujudkan Good Governance Melalui Pelayanan Publik. Yogyakarta: Gajah Mada

Agung Kurniawan. (2005)Transformasi Pelayanan Publik, Yogyakarta: Pembaharuan.

Amirin, M. Tatang. (2010) Skala Likert: Penggunaan dan Analisis Datanya. http://tatangmanguny.wordpress.com /. Diakses tanggal 9 Februari 2016.

Moenir, H. A. S. (1995) Manajemen Pelayanan Umum di Indonesia, Jakarta: Bumi. Aksara.

Batinggi, A \& Ahmad, B. Manajemen pelayanan Umum, Jakarta: Universitas Terbuka

Effendy. (2003) Ilmu Teori dan Filsafat Komunikasi, Bandung: Citra Aditya Bhakti.

Istianto, Bambang. (2009). Manajemen Pemerintahan Dalam Persepektif Pelayanan Publik. Jakarta : Mitra Wacana Media.

Ratminto. Dan Winarsih, Atik Septi. (2010) Manajemen Pelayanan. Yogyakarta: Pustaka Pelajar.

Sedarmayanti. (2001). Sumber Daya Manusia dan Produktivitas Kerja. Bandung: Mandar Maju

Sinambela, Lijan Poltak. (2006) Reformasi Pelayanan Publik (Teori, Kebijakan, dan. Implementasi), Jakarta: Bumi Aksara 
Sugiono. (2013) Metode Penelitian Kuantitatif, Kualitatif dan R\&D. Bandung: Alfabeta

Sutopo dan Suryanto Adi. (2009) Pelayanan Prima. Jakarta: Lembaga Administrasi Negara

Wasistiono. (2001) Kapita Selekta Pemerintahan Daerah. Bandung: Alqaprint Jatinangor

\section{DOKUMEN-DOKUMEN}

UU No. 22 Tahun 2009 tentang Lalu Lintas dan Angkutan Jalan

UU No. 25 Tahun 2009 tentang Pelayanan Publik

KM.35 Tahun 2003. Tentang. Penyelenggaraan Angkutan Orang di Jalan

KEP. MEN .PAN No. 63/KEP/M.PAN/7/2003 tentang Pedoman Umum Penyelenggaraan Pelayanan Publik

Peraturan Menteri Dalam Negeri No. 24 Tahun 2006 tentang Pedoman Penyelenggaraan Pelayanan Terpadu Satu Pintu.

PP. 74 Tahun 2014. Tentang Angkutan Jalan

Perda Kabupaten Bogor Nomor 13 Tahun 2011, Tentang Retribusi Izin trayek 